(2) Open Access Full Text Article

LETTER

\title{
Emerging dermatological and systemic applications of ustekinumab: beyond its clinical use in psoriasis
}

This article was published in the following Dove Press journal:

Clinical, Cosmetic and Investigational Dermatology

19 June 2012

Number of times this article has been viewed

\author{
Shailendra Kapoor \\ Richmond,VA,USA
}

Correspondence: Shailendra Kapoor 2300 E Cary Street, Richmond,

VA 23223, USA

Email shailendrakapoor@yahoo.com
I read with great interest the paper by Uhlenhake and Mehregan in a recent issue of your journal. ${ }^{1}$ The article is highly thought-provoking. Interestingly, the past few years have seen increased use of ustekinumab in clinical applications other than psoriasis.

For instance, ustekinumab is effective for treatment-resistant hidradenitis suppurativa. ${ }^{2,3}$ Similarly, recalcitrant palmoplantar pustulosis responds to treatment with ustekinumab. ${ }^{4}$ When used in patients with pyoderma gangrenosum, ustekinumab attenuates the expression of interleukin- 23 and results in significant resolution of lesions. ${ }^{5}$ Ustekinumab has also shown considerable promise in ameliorating the symptoms of subacute lupus erythematosus and pityriasis rubra. ${ }^{6,7}$

Further, ustekinumab is particularly effective in the treatment of nail psoriasis and erythrodermic psoriasis, both of which are relatively difficult to treat with other standard psoriasis therapies. ${ }^{89}$ Similarly, Alvarez et al and Sanso et al have recently reported the effectiveness of ustekinumab in the management of symptoms of Crohn's disease. ${ }^{10,11}$ Reduction in serum C-reactive protein levels after ustekinumab therapy confirms its effectiveness in Crohn's disease. ${ }^{12}$ Ustekinumab therapy is also promising in the management of graft-versus-host disease, especially in patients who are unresponsive to steroids. ${ }^{13}$

However, ustekinumab needs to be used carefully because its use may be associated with the development of skin malignancies, such as squamous cell carcinoma. ${ }^{14}$ Similarly, malignant melanomas may be associated with ustekinumab therapy. ${ }^{15}$ Also, neurological syndromes, such as posterior leukoencephalopathy, have been reported following administration of ustekinumab. ${ }^{16}$ Severe pustular psoriasis may result as a consequence of ustekinumab therapy in patients being treated for plaque psoriasis. ${ }^{17}$

Clearly, ustekinumab has a major role to play in the management of various systemic conditions. Hopefully, the coming few years will see increased application of ustekinumab in the management of other dermatological conditions besides psoriasis.

\section{Disclosure}

The author reports no conflicts of interest in this work.

\section{References}

1. Uhlenhake EE, Mehregan DA. Ustekinumab: differential use in psoriasis. Clin Cosmet Investig Dermatol. 2011;4:93-99.

2. Sharon VR, Garcia MS, Bagheri S, et al. Management of recalcitrant hidradenitis suppurativa with ustekinumab. Acta Derm Venereol. November 11, 2011. [Epub ahead of print.] 
3. Gulliver WP, Jemec GB, Baker KA. Experience with ustekinumab for the treatment of moderate to severe hidradenitis suppurativa. JEur Acad Dermatol Venereol. May 24, 2011. [Epub ahead of print.]

4. Chu DH, Van Voorhees AS, Rosenbach M. Treatment of refractory tumor necrosis factor inhibitor-induced palmoplantar pustulosis: a report of 2 cases. Arch Dermatol. 2011;147:1228-1230.

5. Guenova E, Teske A, Fehrenbacher B, et al. Interleukin 23 expression in pyoderma gangrenosum and targeted therapy with ustekinumab. Arch Dermatol. 2011;147:1203-1205.

6. De Souza A, Ali-Shaw T, Strober BE, Franks AG Jr. Successful treatment of subacute lupus erythematosus with ustekinumab. Arch Dermatol. 2011;147:896-898.

7. Balestri R, Bardazzi F, Antonucci A. Should ustekinumab really be used as first-line biological therapy in pityriasis rubra pilaris? Br J Dermatol. 2010;163:896-897.

8. Patsatsi A, Kyriakou A, Sotiriadis D. Ustekinumab in nail psoriasis: an open-label, uncontrolled, nonrandomized study. J Dermatolog Treat. August 8, 2011. [Epub ahead of print.]

9. Viguier M, Pages C, Aubin F, et al. Efficacy and safety of biologics in erythrodermic psoriasis: a multicentre, retrospective study. Br J Dermatol. March 13, 2012. [Epub ahead of print.]

10. Alvarez Cuenllas B, Garcia Alvarado M, Vaquero L, et al. Use of ustekinumab in inflammatory bowel disease. apropos of three cases. Gastroenterol Hepatol. February 7, 2012. Spanish. [Epub ahead of print.]
11. Sanso Sureda A, Rocamora Duran V, Sapina Camaro A, Royo Escosa V, Bosque Lopez MJ. Ustekinumab in a patient with Crohn's disease and anti-TNF-alpha-induced psoriasis. Gastroenterol Hepatol. 2011;34: 546-550.

12. Toedter GP, Blank M, Lang Y, Chen D, Sandborn WJ, de Villiers WJ. Relationship of C-reactive protein with clinical response after therapy with ustekinumab in Crohn's disease. Am J Gastroenterol. 2009;104: 2768-2773.

13. Pidala J, Perez L, Beato F, Anasetti C. Ustekinumab demonstrates activity in glucocorticoid-refractory acute GVHD. Bone Marrow Transplant. August 29, 2011. [Epub ahead of print.]

14. Young L, Czarnecki D. The rapid onset of multiple squamous cell carcinomas in two patients commenced on ustekinumab as treatment of psoriasis. Australas J Dermatol. 2012;53:57-60.

15. Ehmann LM, Tillack-Schreiber C, Brand S, Wollenberg A. Malignant melanoma during ustekinumab therapy of Crohn's disease. Inflamm Bowel Dis. 2012;18:E199-E200.

16. Gratton D, Szapary P, Goyal K, Fakharzadeh S, Germain V, Saltiel P. Reversible posterior leukoencephalopathy syndrome in a patient treated with ustekinumab: case report and review of the literature. Arch Dermatol. 2011;147:1197-1202.

17. Gregoriou S, Kazakos C, Christofidou E, Kontochristopoulos G, Vakis G, Rigopoulos D. Pustular psoriasis development after initial ustekinumab administration in chronic plaque psoriasis. Eur J Dermatol. 2011;21:104-105.
Clinical, Cosmetic and Investigational Dermatology

\section{Publish your work in this journal}

Clinical, Cosmetic and Investigational Dermatology is an international, peer-reviewed, open access, online journal that focuses on the latest clinical and experimental research in all aspects of skin disease and cosmetic interventions. All areas of dermatology will be covered; contributions will be welcomed from all clinicians and

\section{Dovepress}

basic science researchers globally. This journal is indexed on CAS The manuscript management system is completely online and includes a very quick and fair peer-review system, which is all easy to use. Visit http://www.dovepress.com/testimonials.php to read real quotes from published authors. 